\title{
Implikasi Yuridis Penetapan Hakim Berkaitan Diversi yang Melanggar Ketentuan Undang-Undang Sistem Peradilan Pidana Anak
}

\author{
Megah Novita Endriyanti ${ }^{1}$, Nurini Aprilianda ${ }^{2}$, Abdul Madjid ${ }^{3}$
}

1 Megah Novita Endriyanti; Fakultas Hukum Universitas Brawijaya; Jl. MT Haryono 169; Malang; 65145; Jawa Timur; Indonesia.

2 Nurini Aprilianda; Fakultas Hukum Universitas Brawijaya; Jl. MT Haryono 169; Malang; 65145; Jawa Timur; Indonesia.

3 Abdul Madjid; Fakultas Hukum Universitas Brawijaya; Jl. MT Haryono 169; Malang; 65145; Jawa Timur; Indonesia.

\begin{tabular}{l}
\hline A R T I C L E I N F O \\
\hline Article history: \\
Received 2019-05-09 \\
Received in revised form \\
2019-06-19 \\
Accepted 2019-07-01 \\
\hline
\end{tabular}

Kata kunci:

Implikasi Yuridis, Penetapan

Hakim, Diversi.

Keywords:

Juridical Implications, Determination of Judges, Divertion.

\section{Citation:}

Endriyanti, M., Aprilianda, N., E Madjid, A. (2019). Implikasi Yuridis Penetapan Hakim Berkaitan Diversi yang Melanggar Ketentuan UndangUndang Sistem Peradilan Pidana Anak. Jurnal Cakrawala Hukum, 10(1).

doi:10.26905/idjch.v10i1.2947

\section{Abstrak}

Diversi ini merupakan proses penyelesaian perkara tindakan pelanggaran hukum yang terjadi yaitu dengan cara mempertemukan pihak korban serta keluarga dan pihak pelaku serta keluarga untuk duduk bersama guna membicarakan proses penyelesaian perkara secara kekeluargaan. Tulisan ini bertujuan untuk menganalisis terkait implikasi yuridis penetapan hakim tentang diversi yang isinya melanggar ketentuan undang-undang sistem peradilan pidana anak. Untuk menjawab tujuan tulisan tersebut, digunakan penelitian hukum normatif, menggunakan pendekatan perundang-undangan digunakan untuk meneliti Undang-undang Sistem Peradilan Pidana Anak, sedangkan pendekatan kasus menggunakan penetapan hakim dalam kasus Anak. Hasil penelitian tersebut menunjukkan bahwa implikasi yuridis penetapan hakim tentang diversi yang isinya melanggar ketentuan undang-undang sistem peradilan pidana anak adalah menjadi dapat dibatalkan, yang mana akibat hukumnya masih dapat dilaksanakan sepanjang tidak ada pihak yang mengajukan pembatalan. Upaya diversi ini merupakan wujud dari keadilan restoratif yang mana bertujuan untuk menghindarkan anak dari proses peradilan. Jadi ketika diversi itu berhasil dilakukan dan timbul kesepakatan, maka itu berarti tujuan keadilan restoratif sudah tercapai.

\section{Abstract}

This diversion is the process of resolving cases of violations of law that occur, namely by bringing together the victims and their families and the perpetrators as well as their families to sit together to discuss the settlement of cases in a family manner. Legislation on the juvenile justice system. To answer the purpose of the 
paper, normative legal research is used, using a legal approach used to examine the Child Criminal Justice System Act, while the case approach uses the determination of judges in the case of Children. The results of the study indicate that the juridical implication of the judges' determination regarding diversion which violates the provisions of the law on juvenile criminal justice systems is that they can be canceled, which can still be carried out as long as no party submits a cancellation. This diversion effort is a manifestation of restorative justice which aims to avoid children from the judicial process. So when the diversion is successfully carried out and an agreement arises, it means that the goal of restorative justice has been achieved.

\section{Latar Belakang}

Anak merupakan salah satu aset berharga yang dimiliki setiap Negara. Masa depan suatu Negara ditentukan oleh Anak sebagai generasi penerusnya, sebagai generasi yang akan meneruskan cita-cita bangsa dan menciptakan kemajuankemajuan di masa yang akan datang. Setiap Negara juga memiliki peraturan perundang-undangan guna mengatur dan mengontrol masyarakatnya. Itulah mengapa setiap Negara sudah pasti memiliki peraturan perundang-undangan yang khusus mengatur tentang anak, dimulai dari perlindungan anak yang merupakan sekumpulan hak-hak yang diperoleh oleh anak dan harus dipenuhioleh Negara dan peraturan perundang-undangan yang mengatur bagaimana menangani anak yang sedang berhadapan dengan hukum.

Anak baik di Indonesia maupun di seluruh dunia ketika berhadapan dengan hukum, bukan hanya duduk sebagai korban, namun ada kalanya juga sebagai pelaku yang berkonflik dengan hukum. Pada dasarnya anak harus dilindungi dan ditumbuhkembangkan di lingkungan yang baik karena setiap pola tingkah laku orang-orang di sekitarnya dijadikan contoh oleh anak dalam berperilaku. Itulah mengapa pentingnya pendidikan untuk anak sejak usia dini, agar mereka tumbuh menjadi seseorang dengan moral yang baik dan terdidik.

Indonesia telah mengatur ketentuan tentang proses penyelesaian perkara pidana yang dila- kukan oleh anak untuk pertama kalinya yaitu bersamaan dengan berlakunya Kitab Undang-Undang Hukum Pidana (KUHP) di Indonesia. KUHP mengatur tentang seseorang yang belum dewasa yang melakukan tindak pidana dengan Pasal 45, 46 dan 47 KUHP. Tahun 1997 Indonesia menerbitkan Undang-Undang Negara Republik Indonesia Nomor 3 Tahun 1997 tentang Pengadilan Anak Lembaran Negara Republik Indonesia Tahun 1997 Nomor 3668 yang selanjutnya disebut dengan UU Pengadilan Anak, yang kemudian dengan lahirnya UU Pengadilan Anak tersebut, Pasal 45, 46 dan 47 KUHP yang digunakan untuk menyelesaikan perkara pidana anak dinyatakan tidak berlaku dan dihapus. Undang-undang tersebut mengatur tentang proses penanganan anak yang terjerat kasus tindak pidana. UU Pengadilan Anak, anak yang sedang menjalani proses pemeriksaan perkara disebut anak nakal yang mana hal tersebut dinilai minimbulkan stigmatisasi bagi anak.

UU Pengadilan Anak dinilai sudah berjalan tidak efektif karena berdampak buruk bagi anak di mata masyarakat karena timbulnya stigmatisasi dan banyak memunculkan recidivist anak, maka diterbitkanlah pembaharuan dari UU Pengadilan Anak tersebut, yaitu Undang-Undang Negara Republik Indonesia Nomor 11 Tahun 2012 tentang Sistem Peradilan Pidana Anak, Lembaran Negara Republik Indonesia Tahun 2012 Nomor 153, Tambahan Lembaran Negara Republik Indonesia Nomor 5332 yang selanjutnya dibaca UU SPPA. 
Pembaharuan dalam UU SPPA mengusung konsep restorative justice, yaitu suatu upaya untuk mengembalikan anak ke masyarakat seperti keadaan semula sebelum terjadi tindak pidana. Untuk mewujudkan upaya tersebut, dalam pembaharuan UU SPPA ini dikenal hal baru, yaitu diversi yang diatur pada pasal 6 sampai pasal 15, diversi ini merupakan proses penyelesaian perkara tindakan pelanggaran hukum yang terjadi yaitu dengan cara mempertemukan pihak korban serta keluarga dan pihak pelaku serta keluarga untuk duduk bersama guna membicarakan proses penyelesaian perkara secara kekeluargaan. Pertemuan tersebut, penyidik anak selaku mediator memberikan kesempatan kepada pelaku untuk menjelaskan seputar gambaran-gambaran mengenai kejadian tindak pidana yang telah dilakukannya. (Marlina, 2009)

Diversi diatur dalam Pasal 6 sampai dengan Pasal 15 UU SPPA. Diversi sendiri lebih dikenal sebagai suatu upaya untuk mengalihkan anak dari proses hukum formal ke proses hukum informal guna menghindarkan anak dari proses hukum yang dapat mengganggu mental dan psikisnya. Setiap tingkat proses hukum mulai dari penyidikan, penuntutan sampai pemeriksaan di pengadilan wajib untuk diupayakan Diversi. Diversi tidak serta merta dilaksanakan pada semua kasus anak, namun pada Pasal 7 ayat (2) UU SPPA menyebutkan bahwa ada syarat-syarat tertentu yang harus dipenuhi, diantaranya kasus yang sedang dialami Anak bukan merupakan pengulangan dan tindak pidana yang dilakukan tidak diancam dengan pidana penjara diatas 7 tahun. (Pasal 7 ayat (2) UU SPPA)

Namun, pada faktanya pelaksanaannya tidaklah sesuai dengan yang tertera di peraturan perundang-undangan. Contohnya yaitu penyidik di Kepolisian Resort Pasuruan Kota yang selanjutnya disebut Polresta Pasuruan, masih mengupayakan diversi terhadap beberapa kasus tindak pidana yang memuat ancaman diatas 7 (tujuh) tahun, tindak pidana kesusilaan contohnya. Tindak pidana kesusilaan yang paling sering terjadiya itu tindak pidana perkosaan dan pencabulan sebagaimana diatur pada pasal 285 dan 289 Kitab UndangUndang Hukum Pidana yang selanjutnya disebut KUHP memuat ancaman pidana penjara 12 dan 9 tahun. Jika dikaitkan dengan Pasal 7 ayat (2) UU SPPA, tindak pidana kesusilaan tersebut tidak dapat diupayakan diversi karena ancaman pidananya diatas 7 (tujuh) tahun penjara. Penyidik Polresta Pasuruan tetap mengupayakan diversi terhadap tindak pidana kesusilaan yang dilakukan oleh Anak dengan berbagai pertimbangan.

Bukan hanya tindak pidana kesusilaan, namun juga tindak pidana lain yang juga memuat ancaman pidana lebih dari 7 (tujuh) tahun, yaitu tindak pidana pencurian dengan pemberatan yang diatur dalam Pasal 363 KUHP. Pasal 363 KUHP berbunyi:

“Diancam dengan pidana penjara paling lama tujuh tahun:

1. Pencurian ternak;

2. Pencurian pada waktu terjadi kebakaran, letusan, banjir, gempa bumi atau gempa laut, gunung meletus, kapal keram, kapal terdampat, kecelakaan kereta api, huru-hara, pemberotakan atau bahaya perang;

3. Pencurian pada waktu malam hari dalam sebuah rumah atau di pekarangan tertutup yang ada rumahnya, yang dilakukan oleh orang yang yang ada di situ tanpa diketahui atau tanpa dikehendaki oleh yang berhak;

4. Pencurian yang dilakukan oleh dua orang atau lebih dengan bersekutu;

5. Pencurian yang untuk masuk ke tempat melakukan kejahatan, atau untuk dapat mengambil barang yang hendak dicuri itu, dilakukan degan merusak, memotong atau memanjat, atau dengan memakai anak kunci palsu, perintah palsu atau pakaian jabatan palsu.

Bila pencurian tersebut dalam nomor 3 disertai dengan salah satu hal dalam nomor 4 dan 5, maka perbautan itu diancam dengan pidana penjara 


\section{Implikasi Yuridis Penetapan Hakim Berkaitan Diversi yang Melanggar Ketentuan Undang-Undang...}

paling lama sembilan tahun." (Pasal 363 KUHP). Proses diversi terhadap Anak yang melakukan tindak pidana sesuai dengan pasal 363 (1) ke-4 (empat) KUHP menghasilkan kesepakatan diversi. Sesuai dengan prosedur yang ditetapkan oleh UU SPPA jika upaya diversi yang dilakukan menghasilkan suatu kesepakatan, maka kemudian penyidik harus segera mengirimkan hasil kesepakatan diversi tersebut untuk dimintakan ketetapan diversi kepada ketua Pengadilan Kota Pasuruan. Lain halnya dengan hasil kesepakatan diversi untuk tindak pidana kesusilaan yang ditolak oleh Ketua Pengadilan Negeri Pasuruan karena dianggap tindak pidana kesusilaan tidak diperbolehkan diupayakan diversi karena memuat ancaman lebih dari 7 (tujuh) tahun penjara, berbeda dengan tindak pidana pencurian pemberatan yang juga memuat ancama pidana penjara 7 (tujuh) tahun penjara, namun Ketua Pengadilan Negeri Pasuruan tetap menerbitkan penetapannya dengan Penetapan Pengadilan Negeri Kota Pasuruan Nomor: 01/Pid Sus_Anak/2014/PN.Psr tertanggal 24 September 2014. Permasalahannya kemudian bagaimana implikasi yuridis penetapan hakim tentang hasil kesepakatan diversi yang isinya melanggar ketentuan UU SPPA.

\section{Metode}

Kajian ini menggunakan pendekatan perundang-undangan (statute approach) dan pendekatan kasus (case approach). Pendekatan perundangundangan digunakan untuk meneliti Undangundang Sistem Peradilan Pidana Anak, sedangkan pendekatan kasus menggunakan penetapan hakim dalam kasus Anak.

Bahan hukum yang berhasil dikumpulkan akan dideskripsikan dengan ditambahkan argumentasi-argumentasi dari peneliti secara utuh dalam artian uraian apa adanya terhadap suatu kondisi atau posisi dari preposisi-preposisi hukum atau non-hukum. Teknik ini kemudian dilanjutkan dengan langkah analisis. Analisis yang dimaksud yaitu analisis yang bersifat evaluatif, dalam artian melakukan evaluasi, juga melakukan interpretasi, dalam artian menjelaskna/menafsirkan norma yang memuat ketentuan sistem peradilan pidana anak.

Teknik interpretasi yang akan digunakan dalam tesis ini yaitu diantaranya interpretasi gramatikal, interpretasi sistematis, dan interpretasi kontekstual. Komparatif membandingkan dalam artian membandingkan norma hukum yang ada dalam peraturan perundang-undangan yang satu dengan peraturan perundang-undangan yang lain. Argumentatif dimaksudkan bahwa landasan pemikiran yang melandasi uraian dalam bab pembahasan didasarkan pada penalaran/ logika hukum.

\section{Pembahasan}

Sistem peradilan pidana anak menawarkan upaya diversi di setiap tingkatan penyelesaian perkara yang melibatkan anak, hal itu guna mencapai tujuan diperbaruinya UU SPPA yaitu keadilan restoratif dan menghindarkan anak dari proses formal. Diversi dilaksanakan sebagaimana yang sudah diatur pada UUSPPA khususnya pada pasal 6 sampai pasal 15. Setalah diversi dilakukan, baik berhasil maupun tidak berhasil, langkah selanjutnya yang harus diambil oleh penyidik juga sudah diatur dalam UU SPPA.

Pasal 12 UU SPPA menjelaskan tentang tahapan yang harus dipenuhi oleh penyidik dalam hal diversi menghasilkan kesepakatan. Kesepakatan diversi bisa dilaksanakan ketika kesepakatan tersebut sudah berbentuk penetapan diversi yang dikeluarkan oleh Pengadilan setempat.

Seperti dalam kasus yang terjadi di Kota Pasuruan, terjadi tindak pidana pencurian dengan terdakwa bernama MS yang memenuhi pasal 363 ayat (2) KUHP, Pengadilan Negeri Kota Pasuruan menerbitkan Surat Penetapan Hakim Kesepakatan Diversi dengan nomor: 01/Pid.Sus_Anak/2014/ 
PN.Psr tertanggal 24 September 2014, yang memuat tentang kesepakatan diversi atas perkara tindak pidana pencurian dengan pemberatan yang memenuhi unsur pada pasal 363 (2) KUHP yang dilakukan oleh anak.

Hakim dalam penetapan tersebut menimbang bahwa dari Laporan Hakim Anak tanggal 24 September 2014, Anak dan Korban telah tercapai kesepakatan Diversi tanggal 24 September 2014, dengan ketentuan sebagai berikut:

1. Bahwa Anak mengakui perbuatannya telah melakukan pencurian sepeda motor, dan menyesali perbuatannya, dan berjanji tidak akan mengulangi perbuatan tersebut maupun perbuatan pidana lainnya;

2. Bahwa Anak masih memiliki hungna persaudaraan dengan korban, dan korban tidak menghendaki untuk Anak dipidana;

3. Bahwa orang tua Anak menyatakan sanggup untuk mendidik Anak sehingga tidak akan mengulangi lagi perbuatannya tersebut dan Anak akan melanjutkan pendidikannya;

4. Bahwa apabila Anak mengulang perbuatannya tersebut, maupun perbuatan pidana lainnya, maka orang tua dan Anak setuju untuk diproses sesuai dengan peraturan yang berlaku;

5. Bahwa mengenai barang bukti dalam perkara ini karena telah tercapai kesepakatn diversi maka terhadap barang bukti tersebut harus dikembalikan kepada pemiliknya.

Memperhatikan ketentuan Pasal 12, Pasal 52 ayat (5) UU SPPA, serta peraturan perundangundangan lain yang bersangkutan maka, Hakim menetapkan:

1. Mengabulkan permohonan Hakim;

2. Memerintahkan Hakim untuk mengeluarkan Penetapan Penghentian Pemeriksaan Perkara;

3. Memerintahkan barang bukti berupa STNKB R-2 Yamaha V-IXION Nopol: N-5974-OJ dan 1 (satu) unit Sepeda Motor R-2 Merk Yamaha V-IXION Nopol: N-5974-OJ warna hitam putih beserta kunci sepeda motor, dikembalikan kepada pemiliknya yang berhak.

4. Memerintahkan Panitera menyampaikan salinan Penetapan kepada Hakim, Penuntut Umum, Pembimbing Kemasyarakatan, Anak/ Orang Tua, Korban dan para Saksi.

Surat penetapan hakim inilah yang akan menjadi pembahasan dalam penelitian ini.

Putusan hakim yang baik dan sempurna yaitu hendaknya dapat diuji dengan 4 kriteria dasar pertanyaan (the four ways test) menurut teori pertimbangan hakim, yaitu diantaranya: (Mulyadi, 2016)

a. Benarkan putusanku ini?

b. Jujurkah aku dalam mengambil keputusan?

c. Adilkah bagi pihak-pihak putusan?

d. Bermanfaatkah putusanku ini?

Segala keputusan hakim harus memuat tentang pasal-pasal yang dituduhkan sesuai dengan peraturan perundang-undangan serta peraturan-peraturan lain yang tidak tertulis yang dijadikan dasar untuk menggali, yang hidup dan berkembang di masyarakat. Proses atau tahapan untuk menjatuhkan suatu pidana menurut Moeljatno dilakukan dengan beberapa tahap yaitu diantaranya: (Rifai, 2010)

1) Tahap Menganalisis Perbuatan Pidana

Dalam tahap ini hakim menganalisis apakah terdakwa melakukan perbuatan pidana atau tidak, yang menjadi bahan primer dalam menganalisisnya yaitu dari segi masyarakat, yaitu perbuatan tersebut sebagai rumusan dalam pasal-pasal suatu aturan pidana.

2) Tahap Menganalisis Tanggungjawab Pidana Dalam tahap ini, hakim menganalisis tentang tanggungjawan terdakwa. Jika terdakwa sudah terbukti melakukan tindak pidana, lantas hakim menganalisis apakah terdakwa dapat mempertanggungjawabkan perbuatannya. Hal 


\section{Implikasi Yuridis Penetapan Hakim Berkaitan Diversi yang Melanggar Ketentuan Undang-Undang...}

inilah yang mempengaruhi pidana apa yang akan dijatuhkan oleh hakim.

3) Tahap Penentuan Pemidanaan

Dalam tahap ini, barulah hakim dapat menjatuhkan pidananya ketika hakim menilai bahwa terdakwa benar-benar melakukan tindak pidana sesuai dengan pasal-pasal yang didakwakan kepadanya.

Hakim dalam menjatuhkan putusan juga harus mempertimbangkan 2 (dua) hal yang penting, diantaranya: (Rifai, 2010)

a. Faktor Yuridis

Faktor yuridis memuat tentang pasal-pasal yang terdapat dalam peraturan perundang-undangan hukum pidana maupun yang berkaitan dengan hukum pidana serta teori-teori hukum pidana.

b. Faktor Non Yuridis

Faktor non yuridis memuat tentang analisis hakim mengenai lingkungan terdakwa penilaian dari hati nurani hakim itu sendiri.

Sekilas dalam Penetapan Hakim nomor: 01/ Pid.Sus._Anak/2014/PN.Psr. memang tidak ada masalah, hakim mengabulkan permohonan penetapan diversi oleh penyidik terhadap seseorang dibawah umur yang melakukan pencurian, yang mana diversinya berhasil karena pelaku masih memiliki hubungan persaudaraan dengan korban.

Hakim dalam memutuskan suatu perkara harus dengan pertimbangan-pertimbangan yang logis, sama halnya dengan penyidik dalam membuat diskresinya untuk melaksanakan diversi terhadap kasus yang tidak memenuhi syarat dilakukan diversi dalam pasal 7 ayat (2) UU SPPA. Pertimbangan sebagaimana yang sudah dituangkan dalam Penetapan Hakim tersebut yaitu yang pertama Anak telah mengakui perbuatannya, yaitu apa yang dilaukannya dengan mencuri sesuatu milik orang lain adalah perbuatan salah dan termasuk perbuatan yang diancam dengan pidana.
Pernyataan Anak untuk bersedia tidak mengulangi perbuatan tersebut dan tidak melakukan perbuatan pidana apapun di kemudian hari. Sebagaimana teori tujuan permidanaan relatif khusus yang mengatakan bahwa pidana bertujuan untuk mencegah penjahat dalam mengulangi perbuantannya lagi yaitu dengan diberikan pidana yang dapat memberikan efek jera, dan tujuan dari UU SPPA untuk menghindarkan Anak dari proses penyelesaian perkara pidana formal, dengan adanya penetapan ini, meskipun Anak tidak mendapatkan hukuman pidana baik berupa pidana maupun tindakan, namun tujuan pemidanaan untuk membuat penjahat mengakui perbuatannya, menyadari perbuatannya itu merupakan sesuatu yang salah dan berjanji untuk tidak mengulanginya lagi di kemudian hari sudah tercapai.

Dengan dilakukannya diversi terhadap kasus tersebut, meskipun pelaksanaannya melanggar ketentuan yang terdapat dalam UU SPPA, namun tujuan pemidanaan pembinaan yang memang dikhususkan untuk Anak sudah sesuai.

Penetapan hakim terbit ketika penyidik menyerahkan Surat Hasil Kesepakatan Diversi kepada Ketua Pengadilan Negeri yang berkompeten. Dengan berbagai pertimbangan, Ketua Pengadilan Negeri mengeluarkan Surat Penetapan Diversi yang artinya juga memerintahkan kepada penyidik untuk melakukan pemberhentian penyidikan terhadap kasus Anak tersebut.

Perlu dijelaskan terlebih dahulu perbedaan antara putusan dan penetapan hakim itu sendiri. Menurut KUHAP, yang dimaksud dengan putusan hakim yaitu suatu pernyataan hakim yang diucapkan di muka persidangan yang terbuka untuk umum, yang dapat berupa pemidanaan, atau bebas atau lepas dari segala tuntutan hukum dalam hal yang diatur oleh KUHAP. Sedangkan penetapan menurut KUHAP yaitu keputusan pengadilan atas perkara yang berupa permohonan. Dalam hal ini, ketika proses diversi tersebut menghasilkan suatu kesepakatan, maka penyidik menyerahkan surat 
hasil kesepakatan diversi tersebut kepada Ketua Pengadilan Negeri untuk kemudian dibuatkan Surat Penetapan Hakim tentang diversi.

Kemudian Ketua Pengadilan Negeri meninjau kasus dan surat kesepakatan diversi tersebut, hingga melalui pertimbangannya pula ditetapkan kesepakatan diversi tersebut untuk kemudian dilaksanakan oleh pihak-pihak yang terkait. Dalam hal ini, setelah penyidik melaksanakan diversi dengan berbagai pertimbangannya, kemudian dihasilkan suatu kesepakatan, lalu penyidik meminta kepada Ketua Pengadilan Negeri Kota Pasuruan untuk menerbitkan surat penetapan diversi. Bermula dari pelaksanaan diversi yang sudah melanggar ketentuan yang ada dalam UU SPPA, saat dimintakan surat penetapan hakim pun, oleh Ketua Pengadilan Negeri Kota Pasuruan juga dikabulkan.

Jika upaya diversi tetap dilakukan meski melanggar ketentuan, maka surat penetapan yang diterbitkan oleh Ketua Pengadilan Negeri Kota Pasuruan juga dapat dikatakan melanggar ketentuan peraturan perundang-undangan juga. Surat penetapan tersebut akan menimbulkan 2 (dua) implikasi yaitu yang pertama menjadi dapat dibatalkan atau batal demi hukum. Surat penetapan tersebut dapat dibatalkan dikemudian hari ketika terdapat salah satu pihak yang mengajukan pembatalan, sedangkan surat penetapan tersebut menjadi batal demi hukum tanpa pembatalan terlebih dahulu dan dianggap tidak pernah ada putusan atau penetapan seperti sebelumnya ketika surat penetapan tersebut menjadi batal demi hukum.

Pada dasarnya, surat penetapan diversi tersebut bersifat seperti perjanjian sebagaimana yang ada dalam hukum perdata. Perjanjian disini yaitu terdiri dari pihak pelaku dan pihak korban untuk memberikan sesuatu, tidak memberikan sesuatu atau untuk melakukan sesuatu. Seperti halnya dalan hukum perdata, terdapat syarat pula yang harus dipenuhi agar surat perjanjian tersebut dapat dianggap sah. Syarat yang harus dipenuhi dalam suatu perjanjian mengacu pada pasal 1320 Kitab
Undang-Undang Hukum Perdata yaitu diantaranya: (Waluyo, 2011)

a. Kesepakatan para pihak dalam perjanjian

b. Kecakapan para pihak dalam perjanjian

c. Suatu hal tertentu

d. Sebab yang halal

Kecuali dalam unsur objek yang diperjanjian dalam Pasal 1332 KUHPer yang mana menyebutkan objek perjanjian harus berupa barang-barang yang dapat diperdagangkan, hal ini tidak berlaku dalam surat perjanjian kesepakatan diversi karena UU SPPA sudah mengaturnya lebih lanjut dalam Pasal 11 UU SPPA. Unsur kecakapan yang diatur oleh KUHPer pada Pasal 1330 juga tidak berlaku dalam surat perjanjian penetapan diversi karena tujuan UU SPPA yaitu melindungi dan menjamin hak-hak pelaku. Jika dalam Pasal 1330 KUHPer melarang seseorang yang belum dewasa untuk terlibat dalam suatu perjanjian karena dianggap belum cakap, lain halnya dengan surat kesepakatan diversi, anak baik duduk sebagai pelaku maupun korban juga harus diperhitungkan pula pendapatnya dalam pembuatan kesepakatan diversi. Akan tetapi, proses pelaksanaan diversi itu sendiri harus juga didampingi oleh orang dewasa, seperti orang tua/ wali dari anak yang terlibat.

Jika perjanjian dalam KUHPer tersebut diterapkan dalam surat penetapan kesepakatan diversi dalam Hukum Pidana, dapat dikatakan sama. Yaitu dalam unsur pertama yaitu terjadinya kesepakatan, yang mana diversi tersebut dianggap berhasil dan sampai pada tahap terbitnya Surat Penetapan Hakim dikarenakan telah terjadi kesepakatan antara pihak keluarga korban dan pihak keluarga pelaku untuk menyelesaikan perkara pidana tersebut secara kekeluargaan, itulah mengapa kemudian para pihak membuat kesepakatan-kesepakatan untuk kemudian dimintakan penetapan kepada Ketua Pengadilan setempat.

Jika dalam KUHPer syarat sahnya perjanjian yang kedua yaitu cakap, dalam hukum pidana per- 
janjian atau kesepakatan yang dihasilkan melalui diversi ini ada karena adanya ketidak cakapan dari pihak pelaku, yaitu pelaku merupakan seseorang yang masih belum dewasa, dalam hal ini dewasa menurut hukum pidana yaitu umur 18 tahun yang terbukti telah melakukan tindak pidana, yang mana dalam proses penyelesaian perkara pidana tersebut mengenal adanya suatu penyelsaian melalui diversi sebagai upaya untuk menghindarkan Anak dari proses penyelesaian perkara pidana formal. Itulah mengapa kesepakatan ini meskipun tidak dapat dianggap sah dalam perjanjian hukum perdata karena salah satu pihak belum dewasa, berbeda dengan hukum pidana, perjanjian atau kesepakatan diversi ini ada untuk melindungi seseorang yang belum dewasa dari stigmatisasi masyarakat terhadapnya yang dapat mengganggu psikis dan mentalnya yang juga akan memberi dampak buruk bagi masa depannya.

Syarat perjanjian ketiga dalam KUHPer yaitu adanya objek tertentu. Hukum pidana, yang menjadi acuan dari kesepakatan ini yaitu UU SPPA yang mana dalam undang-undang tersebut mengatur lebih rinci tentang diversi. Sesuatu yang dijadikan objek perjanjian dalam hukum perdata yang jika dibandingkan dengan hukum pidana, objek perjanjian tersebut berbentuk kesepakatankesepakatan yang akan dipenuhi oleh para pihak. Sama halnya dengan hukum perdata, prestasi terbagi menjadi 3 hal yaitu diantara melakukan sesuatu, tidak melakukan sesuatu dan memberikan sesuatu. Kesepakatan diversi yang ada pada hukum pidana juga mengandung hal yang sama, yaitu untuk melakukan sesuatu, tidak melakukan sesuatu dan memberikan sesuatu.

Kesepakatan diversi menurut pasal 11 UU SPPA mengandung kesepakatan untuk berdamai dengan korban baik dengan melakukan ganti rugi yang telah dialami korban maupun tidak melakukan ganti rugi, menyerahkan Anak kembali kepada orang tuanya untuk dididik dan dibimbing dengan baik, melakukan keikutsertaan dalam pen- didikan atau pelatihan di lembaga pendidikan dan melakukan pelayanan masyarakat. Unsur prestasi yang lain yaitu salah satunya memberikan sesuatu yang dalam kesepakatan diversi dapat disama artikan dengan memberikan sesuatu oleh pelaku kepada korban sebagai bentuk ganti rugi.

Adapun syarat keempat dalam perjanjian Hukum Perdata, dalam kesepakatan diversi Hukum Pidana juga memuat klausa yang halal yaitu kesepakatan tersebut tidak bertentangan dengan ketentuan umum dan kesusilaan. Kesepakatan diversi dilakukan berdasarkan Pasal 6 hingga 15 UU SPPA. Dasar hukum dilaksanakannya diversi sudah diatur dalam UU SPPA, yang berarti jika terjadi kesepakatan dalam diversi tersebut, kesepakatandianggap tidak melanggar ketentuan umum.

Jadi, seperti perjanjian biasa pada umumnya yang ada dalam KUHPer, kesepakatan diversi juga dapat diajukan pembatalan atau bahkan batal demi hukum jika salah satu syarat tersebut tidak dipenuhi. Adapun dalam Hukum Perdata, yang dimaksud dengan syarat formil yaitu syarat yang ada pada subyek perjanjiannya, yaitu kesepakatan dan pihak-pihak yang ada dalam perjanjian, selama unsur subyektif dalam kesepakatan diversi telah terpenuhi maka perjanjian dapat dilaksanakan, namun jika salah satu tidak terpenuhi, dalam hal ini, diversi menghasilkan suatu kesepakatan yang hanya disepakati oleh salah satu pihak, baik hanya pihak pelaku maupun pihak korban saja, maka surat penetapan kesepakatan diversi tersebut menjadi dapat dibatalkan, yang artinya perjanjian tersebut akan terus dilaksanakan sepanjang tidak terdapat salah satu pihak yang mengajukan pembatalan.

Syarat obyektif dalam suatu perjanjian yaitu terdapat dalam poin c dan d, yaitu suatu hal tertentu dan sebab yang halal. Jika syarat obyektif dalam suatu perjanjian salah satunya tidak terpenuhi, maka perjanjian tersebut menjadi batal demi hukum, seluruh akibat hukum yang diha- 
silakan dari kesepakatan tersebut dianggap tidak pernah ada seperti sebelumnya, yang mana dalam hukum pidana jika surat penetapan hakim tersebut sudah batal demi hukum, maka penyidik harus segera menyerahkan berkas perkara kepada penuntut umum untuk segera dilanjutkan ke proses berikutnya yaitu penuntutan.

Kasus ini, surat penetapan hakim No. 01/ Pid.Sus_Anak/2014/PN.Psr menjadi batal demi hukum karena unsur subyektif sudah terpenuhi yaitu terjadi kesepakatan antara pihak pelaku dan pihak korban, hanya saja pelaksanaan diversi tersebut melanggar ketentuan UU SPPA karena seharusnya untuk kasus pencurian dengan pemberatan ini tidak dapat diupayakan diversi karena memuat ancaman penjara lebih dari 7 (tujuh) tahun penjara, yaitu 9 (sembilan) tahun penjara, namun oleh penyidik tetap dilaksanakan. Oleh karenanya, unsur yang tidak dipenuhi dalam surat penetapan diversi tersebut adalah syarat obyektif yang mana implikasinya menjadi batal demi hukum. Yang artinya, kesepakatan-kepakatan yang ada dalam surat penetapan diversi dianggap tidak pernah ada, dan penyidik harus melanjutkan ke proses selanjutnya.

Namun bagaimanapun juga, konsep perjanjian yang ada dalam hukum perdata tidak dapat disamakan dengan hukum pidana, karena dalam hukum perdata bersifat privat yang mana perjanjian tersebut hanya berpengaruh terhadap para pihak saja, dalam hal terjadinya perkara, pihak yang berpengaruh dalam perjanjian yaitu penggugat dan tergugat. Sedangkan hukum pidana yang bersifat publik, maka dalam kesepakatan diversi bukan hanya pelaku dan korban yang dilibatkan, namun juga ada masyarakat yang merasa dirugikan atau terganggu dengan terjadinya tindak pidana yang dilakukan oleh Anak.

M. Nasir Djamil berpendapat bahwa (2013)

Implementasi dari keadilan restoratif yaitu suatu upaya diversi, yang kemudian diversi itu berupaya mengembalikan pemulihan terhadap se- buah permasalahan, bukan sebuah pembalasan yang selama ini dikenal dalam hukum pidana. Itulah mengapa kemudian pemahaman bahwa menjauhkan anak dari proses peradilan menjadi penting karena hal ini disamping merupakan tujuan tercapainya keadilan restoratif juga sebagai bagian upaya perlindungan hak asasi anak sebagaimana yang tercantum dalam Konvensi Hak Anak Pasal 37 (b), The Beijing Rules (Butir 13.1 dan 2). Sejalan dengan hal tersebut dalam Konvensi Hak Anak Pasal 40 dan The Beijing Rules (Butir 6 dan Butir 11.1, 2, 3 dan 4) diberikan peluang bagi dilakukannya diversi atau pengalihan perkara oleh polisi dan penuntut umum serta pejabat lain yang berwenang untuk menjauhkan anak dari proses peradilan formil, penahanan atau pemenjaraan. Upaya diversi ini dilakukan dengan menempatkan anak dibawah pengawasan badan-badan sosial tertentu yang membantu pelaksanaan sistem peradilan pidana anak sebagaimana disebutkan dalam undangundang.

Sebagaimana juga disebutkan dalam The Beijing Rules, bahwa dipandang penting adanya jaminan bagi para aparat penegak hukum untuk mengambil tindakan-tindakan kebijaksanaan dalam menangani atau menyelesaikan masalah dan kejahatan yang melibatkan anak, dengan tidak mengambil jalan formal, seperti menghentikan atau tidak meneruskan melalui proses peradilan pidana atau mengembalikan/menyerahkan kepada masyarakat atau orang tua dan bentuk-bentuk pelayanan sosial lainnya.(Aprilianda, 2017)

Kusno Adi menyimpulkan bahwa dalam Resolusi PBB 45/113 memuat ketentuan-ketentuan yaitu yang pertama, meski dimungkinkan proses peradilan pidana terhadap anak, tetapi lebih diprioritaskan agar anak terhindar dari proses peradilan. Hal ini didasarkan atas pertimbangan, bahwa persinggungan seorang anak dengan aparat peradilan mulai polisi, jaksa, hakim, advokat dan lembaga pemasyarakatan, akan memberikan dampak negatif terhadap anak. Persinggungan seorang 


\section{Implikasi Yuridis Penetapan Hakim Berkaitan Diversi yang Melanggar Ketentuan Undang-Undang...}

Megah Novita Endriyanti, Nurini Aprilianda, Abdul Madjid

anak dalam dunia peradilan juga akan melahirkan stigmatisasi, yang justru dapat menghambat proses pembinaan terhadap anak itu sendiri. Yang kedua, sekiranya proses peradilan itu tetap tak dapat dihindari maka hak-hak dan kepentinganan anak harus menjadi pertimbangan utama sebab peradilan anak harus tetap bermuara pada tujuan utamanya yaitu kesejahteraan baik fisik maupun mental anak. Yang terakhir, makna esensinya adalah bahwa manakala ada alternatif diluar proses peradilan pidana maka proses penyelesaian perkara anak lebih diutamakan menggunakan alternatif diluar proses peradilan. (Aprilianda, 2017)

Berdasarkan uraian diatas dapat ditarik benang merah bahwasanya, adanya upaya diversi ini merupakan wujud dari keadilan restoratif yang mana bertujuan untuk menghindarkan anak dari proses peradilan. Jadi ketika diversi itu berhasil dilakukan dan timbul kesepakatan, maka itu berarti tujuan keadilan restoratif sudah tercapai.

Diversi tersebut tetap tidak harus dilakukan karena dalam ketentuan UU SPPA tidak boleh dilaksanakan karena tidak memenuhi syarat seperti yang diatur dalam Pasal 7 ayat (2) UU SPPA, lalu menghasilkan suatu kesepakatan dan sudah ditetapkan oleh Pengadilan Negeri setempat, meski keadilan restoratif sudah tercapai dan tujuannya terpenuhi. Implikasi dari surat penetapan hakim mengenai kesepakatan diversi yaang melanggar ketentuan UU SPPA juga seharusnya menjadi batal demi hukum, karena dalam surat penetapan tersebut unsur peraturan perundang-undangannya tidak terpenuhi. Meskipun tujuan keadilan restoratif dan maksud dari diadakannya diversi sudah terpenuhi, tetap sajasurat penetapan tersebut tidak seharusnya ada. Konsekuensi dari batalnya suatu penetapan hakim yaitu pengulangan proses. Pengulangan proses yang dimaksud di atas yaitu pengulangan proses diversinya. Diulang seperti saat memulai proses penyidikan sesuai dengan ketentuan UU SPPA.

Namun saat dalam proses penyidikan, menurut ketentuan UU SPPA, tindak pidana pencurian dengan pemberatan yang sesuai dengan pasal 363 ayat (2) KUHP tidak dapat dilaksanakan diversi karena tindak pidana tersebut memuat ancaman pidana penjara lebih dari 7 (tujuh) tahun, yaitu 9 (sembilan) tahun. Maka dengan begitu, penyidik wajib melanjutkan perkara ke tahap selanjutnya, yaitu penuntutan.

\section{Simpulan}

Diversi yang tetap dilakukan oleh penyidik Anak meskipun melanggar ketentuan yang ada pada Undang-undang Sistem Peradilan Pidana Anak khususnya pada pasal 7 ayat (2) yang mana hasil kesepakatan tersebut telah menjadi Surat Penetapan Hakim setempat, implikasinya menjadi batal demi hukum. Artinya kesepakatan-kesepakatan yang tercantum di dalam surat penetapan hakim tersebut serta segala akibat hukum dianggap tidak pernah ada seperti sebelumnya. Konsekuensi dari batal nya surat penetapan yaitu pengulangan proses penyidikan dan dilanjutkan pada tahap selanjutnya.

\section{Daftar pustaka}

Aprilianda, Nurini. 2017. Perlindungan Anak Korban Kekerasan Seksual melalui Pendekatan Keadilan Restoratif. Jurnal Arena Hukum. Volume 10. Nomor 2.

Kitab Undang-Undang Hukum Pidana (KUHP).

Marlina. 2009. Peradilan Pidana Anak di Indonesia: Pengembangan Konsep Diversi dan Restorative Justice. Bandung. Refika Aditama.

Mulyadi, Lilik. 2016. Kekuasaan Kehakiman. Surabaya. Bina Ilmu.

Packer. Herbert, L. 2011. The Limits of the Criminal Sanction. California. Stanford University Press.

Republik Indonesia. 2015. Peraturan Pemerintah Nomor 65 Tahun 2015 tentang Pedoman Pelaksanaan Diversi dan Penanganan Anak yang Belum Berusia 12 (Dua Belas) Tahun. (Lembaran Negara Republik Indoneisa Nomor 194 Tahun 2015. Tambahan 


\section{Jurnal Cakrawala Hukum, Volume 10 No. 1 Juni 2019}

ISSN PRINT 2356-4962 ISSN ONLINE 2598-6538

Lembaran Negara Republik Indonesia Nomor 5732).

Republik Indonesia. 1981. Undnag-Undang Negara Republik Indonesia Nomor 8 Tahun 1981 tentang Kitab Undang-Undang Hukum Acara Pidana (KUHAP). Lembaran Negara Republik Indonesia Nomor 76 Tahun 1981.

Republik Indonesia. 2012. Undang-Undang Negara Republik Indonesia Nomor 11 Tahun 2012 tentang
Sistem Peradilan Pidana Anak. Lembaran Negara Republik Indonesia Nomor 153 Tahun 2012. Tambahan Lembaran Negara Republik Indonesia Nomor 5332 Tahun 2012.

Rifai, Ahmad. 2010. Penemuan Hukum. Jakarta. Sinar Grafika.

Waluyo, Bambang. 2011. Viktimologi Perlindungan Korban dan Saksi. Jakarta. Sinar Grafika. 